\title{
Factors Associated With Obesity Among Adolescents in Surakarta City
}

\author{
Dittasari Putriana \\ Postgraduate of Nutrition Science \\ Faculty of Medicine, University of Sebelas Maret \\ Surakarta, Indonesia \\ dittaputriana@gmail.com
}

\author{
Dono Indarto \\ Departement of Physiology \\ Faculty of Medicine, University of Sebelas Maret \\ Surakarta, Indonesia \\ dono@staff.uns.ac.id
}

\author{
Adi Magna Patriadi Nuhriawangsa \\ Program of Animal Husbandry \\ Faculty of Agriculture, University of Sebelas Maret \\ Surakarta, Indonesia \\ adimagna@staff.uns.ac.id
}

\begin{abstract}
The prevalence of obesity in children and adolescents in the world has continouosly increased. Some adolescents who lack night sleep tend to consume less plain water and more sweet beverages. Therefore, it will increase energy intake and decrease energy expenditure. This study aimed to analyze the association between sleep duration and consumption of plain water and sweet beverage and obesity risk in adolescents. A total of 248 adolescents who aged 15-18 years old from six senior high schools in Surakarta city participated in this observational analytic study. Data of sleep duration were collected using questionairre and data of plain water and sweet beverage consumption were obtained using 24 hours food recall for 3 alternating days. Body mass index (BMI) for age in percentile was used to determine obesity. Data analysis used chi-square, fisher's exact and multiple logistic regression tests with the significance level $<0.05$. The prevalence of obesity in adolescents was $25 \%$. Shorter sleep duration and inadequate plain water consumption were observed in $87.9 \%$ and $94.8 \%$ of adolescents respectively. Whiles $\mathbf{5 0 . 4 \%}$ adolescents consumed highly sweet beverages. Short sleep duration and inadequate plain water consumption did not increase risk of obesity in adolescents. However, high consumption of sweet beverages increased 1.62 times risk of obesity in adolescents $(95 \% \mathrm{CI}=\mathbf{0 . 8 8}-2.96)$ but not statistically significance $(p=0.118)$. Higher consumption of sweet beverages can increase risk of obesity in adolescents in Surakarta city.
\end{abstract}

Keywords - obesity; adolescents; sleep duration; plain water consumption; sweet beverage consumption

\section{INTRODUCTION}

The global prevalence of obesity in children and adolescents has risen from $4 \%$ in 1975 to $18 \%$ in 2016 [1]. In Indonesia, the national prevalence of obesity is $18.8 \%$ in children, $11.1 \%$ in early adolescents and $7.3 \%$ in late adolescents [2]. While in Central Java Province, $28.9 \%$ people who aged $>15$ years old have obesity. Surakarta which is one of the biggest city in Central Java has $4.8 \%$ higher prevalence of obesity than that of in Central Java [3]. However, few studies have reported what factors contribute in the high prevalence of obesity in Surakarta city.

Besides that, obesity in early life periods also has several biopsychosocial impacts, which were published in some international journals. For example, 3.7 folds greater diabetes risk was observed in UK obese children and adolescents, compared with normal weight counterparts [4]. A strong association between obesity and metabolic syndrome was also reported in Chinese children and adolescents (OR: 67.33 for overweight and 249.99 for obese) [5]. Moreover, childhood obesity increases depression and behavioural/emotional disorders and decreases self-esteem, quality of life and academic performance [6], [7].

Genetic and environmental factors play important roles in the pathogenesis of obesity in children and adolescents. From a study conducted in Surakarta city, childhood obesity is strongly asssociated with obesity status from their parent [8]. There are a large number of polymorphic genes that are asssociated with obesity as well [9]. Although the genetic factor is clearly involved in obesity, environmental factor also contributes in the pathogenesis of obesity. Diet, social and economic status, chemical exposures, lifestyle changes, physical activity and infections are recently known as risk factors for obesity [10]. Dietary habits like more consumption of fried foods and sweet beverages, and less consumption of fruits, vegetables and plain water are commonly found in adolescent daily life [11], [12]. Meanwhile, other factors such as short sleep duration, smoking, pshycological stress and sedentary lifestyle frequently occur in adolescent life as well [10], [12], [13].

Consumption of plain water and sweet beverages has opposite effects in obesity. Research studies in childhood and adulthood females suggest that increased consumption of plain water results in high energy expenditure and decreased body weight and body fat [14], [15]. In addition, Lakoro et al. (2013) reported that 164 Indonesian children who consumed 
less plain water has 2.1 times higher risk of obesity [11] Contrasting with plain water consumption, children and adolescents who consumed sweet beverages more than 1 time/day would increase energy intake and decrease energy expenditure [16]. Three point forty six times greater risk of obesity was observed in 174 obese children and adolescents who consumed $>4$ times/week sweet beverages, compared with their counterpart who consumed $<4$ times/week sweet beverages [17].

Lack of night sleep during adolescent life has negative effects in terms of poor diet quality and excessive food intake [13]. Adolescents with shorter night sleep tend to consume snacks or meals with high energy, fat and sugar [18]. Food intake also increases in adolescents who have shorter night sleep because they have more time awake and opportunities to eat than adolescents who have longer night sleep [13]. Several studies have indicated that some children and adolescents with shorter night sleep have around 2 times higher risk of overweight and obesity as children and adolescents with longer night sleep [19]-[21]. Therefore, this study aimed to analyze the association between sleep duration and consumption of water and sweet beverages and obesity risk in adolescents in Surakarta city.

\section{MethodS}

\section{A. Study Design and Subjects}

This study was an observational analytic study with the cross-sectional design which was conducted from May to August 2017. Population of this study was adolescents who aged 15-18 years old in senior high schools in Surakarta city. Sample size was calculated using a cross-sectional formula based on prevalence of obesity, confidence interval (CI) and absolute precission [22]. The selection of senior high schools was based on latest results of national examination. A total of 248 research subjects were randomly selected from year $\mathrm{X}$ and XI of 3 higher and 3 lower performances of senior high schools. Students were eligible to become research subjects if they had BMI for age $>5$ th percentile, did not consume drugs which could increase or decrease body weight and followed the interview for 3 alternating days. The research protocol of this study was approved by the Health Research Ethics Committee of Dr. Moewardi hospital/Faculty of Medicine, Universitas Sebelas Maret with number 353/IV/HREC/2017.

\section{B. Data Collection}

Selected students were asked their age, sex and family history of obesity and then interviewed their night sleep duration by using questionnaire for three alternating days. The sleep data were categorized into short ( $<8$ hours) and long $(\geq 8$ hours) night sleep [23]. Consumption of plain water and sweet beverages were determined using 24 hours food recall for 3 alternating days and consumption data were converted into $\mathrm{ml} /$ day. According to recommendation of the Indonesian Ministry of Health, plain water consumption in adolescents was categorized into inadequate $(<2000 \mathrm{ml} /$ day $)$ and adequate
( $\geq 2000 \mathrm{ml} /$ day) [24]. Consumption of sweet beverages including tea, coffee, fruit flavour drinks, milk, fruit/vegetable juices, syrup, soft drinks, and energy drinks was categorized into low $(<$ mean) and high $(\geq$ mean) [25]. For BMI calculation, student's height and weight were measured using microtoise (SH-2A, GEA) and digital body weight scale (SRF-9332, Serenity), respectively. Obesity status was determined using BMI for age based on WHO Anthro Plus+ and presented as a percentile with 3 categories: normal (585th percentile), overweight (85-95th percentile) and obese ( $\geq 95$ th percentile) [26]

\section{Statistical Analysis}

The chi-square test was used to analyze the association between sex, family history of obesity, sweet beverage consumption and sleep duration and obesity risk. While, the association between plain water consumption and obesity risk was analyzed using the fisher's exact test. Because there were four variables which had $p$ value $<0.25$, multiple logistic regression test was used to analyze their association with obesity risk simultaneously and to calculate the odd ratios (ORs) and 95\% CIs for obesity risk in relation to short duration of night sleep, low consumption of plain water and high consumption of sweet beverages [27], [28]. The significance value was set up $<0.05$.

\section{RESULTS}

Table I showed the characteristics of adolescents who participated in this study like age, body weight, height, family history of obesity, BMI for age, consumption of plain water and sweet beverages and sleep duration. The mean age of 248 adolescents was $16.06 \pm 0.59$ years old and $73.4 \%$ were female. Eleven point seven percent adolescents had family history of obesity, which $13.2 \%$ was in female and $7.6 \%$ was in male. Of the adolescents, 24 were overweight $(9.7 \%)$ and 38 were obese $(15.3 \%)$. In addition, male adolescents had higher percentage of overweight $(12,1 \%)$ and obese $(21.2 \%)$ than female adolescents $(8.8 \%$ and $13,2 \%$, respectively). Shorter sleep duration was observed in $87.4 \%$ of female adolescents and $89.4 \%$ of male adolescents. A total of $94.8 \%$ adolescents consumed inadequate plain water which female adolescents was higher than male adolescents (96.9\% vs. 93.9\%). Low consumption of sweet beverages in all adolescents was comparable with high consumption of sweet beverages (49.4\% vs. 50.4\%). Male adolescents consumed higher sweet beverages than female adolescents $(62.1 \%$ vs. $46.2 \%)$.

As can be seen from Table II, there was no significant association between all variables and increased risk of obesity in adolescents. From 62 overweight and obese (ovb) adolescents, $64.5 \%$ was female and $35.5 \%$ was male. Male adolescents had 1.77 times greater risk of obesity (95\% $\mathrm{CI}=0.95-3.30)$ than female adolescents but it was not significant $(\mathrm{p}=0.068)$. However, there were only $17.7 \%$ ovb adolescents who had family history of obesity. Those adolescents with family history of obesity were 2.01 times more likely to be obesity $(95 \% \mathrm{CI}=0.89-4.54$; $\mathrm{p}=0.087)$. More 
than $80 \%$ normal and ovb adolescents had shorter sleep duration and shorter sleep duration was negatively associated with obesity risk $(\mathrm{OR}=0.53 ; 95 \% \mathrm{CI}=0.24-1.18$; $\mathrm{p}=0.115)$. Inadequate plain water consumption was very common in normal and ovb adolescents (95.2\% and $93.6 \%$, respectively). Inadequate plain water consumption was negatively associated with obesity risk $(\mathrm{OR}=0.74 ; 95 \% \mathrm{CI}=0.22-2.48)$ but it was not significant $(\mathrm{p}=0.742)$.

TABLE I

BASIC CHARACTERISTICS OF ADOLESCENTS

\begin{tabular}{|c|c|c|c|c|c|c|c|}
\hline & \multicolumn{2}{|c|}{ Female $(n=182)$} & \multicolumn{2}{|c|}{ Male $(n=66)$} & \multicolumn{2}{|c|}{ Total $(n=248)$} & \multirow{2}{*}{ Mean \pm SD } \\
\hline & $n$ & $\%$ & n & $\%$ & $\mathbf{n}$ & $\%$ & \\
\hline Age (years old) & & & & & & & $16.06 \pm 0.59$ \\
\hline Body weight (kg) & & & & & & & $56.11 \pm 13.43$ \\
\hline Height $(\mathrm{cm})$ & & & & & & & $157.93 \pm 8.29$ \\
\hline $\begin{array}{l}\text { Family History of Obesity } \\
\text { No } \\
\text { Yes }\end{array}$ & $\begin{array}{c}158 \\
24\end{array}$ & $\begin{array}{l}86.8 \\
13.2\end{array}$ & $\begin{array}{c}61 \\
5\end{array}$ & $\begin{array}{c}92.4 \\
7.6\end{array}$ & $\begin{array}{c}219 \\
29\end{array}$ & $\begin{array}{l}88.3 \\
11.7\end{array}$ & \\
\hline $\begin{array}{l}\text { BMI for age (percentile) } \\
\text { Normal } \\
\text { Overweight } \\
\text { Obese }\end{array}$ & $\begin{array}{c}142 \\
16 \\
24 \\
\end{array}$ & $\begin{array}{c}78.0 \\
8.8 \\
13.2 \\
\end{array}$ & $\begin{array}{c}44 \\
8 \\
14 \\
\end{array}$ & $\begin{array}{l}66.7 \\
12.1 \\
21.2 \\
\end{array}$ & $\begin{array}{c}186 \\
24 \\
38 \\
\end{array}$ & $\begin{array}{c}75.0 \\
9.7 \\
15.3 \\
\end{array}$ & $55.11 \pm 30.99$ \\
\hline $\begin{array}{l}\text { Sleep duration (hours/day) } \\
\text { Short } \\
\text { Long }\end{array}$ & $\begin{array}{c}159 \\
23\end{array}$ & $\begin{array}{l}87.4 \\
12.6\end{array}$ & $\begin{array}{c}59 \\
7\end{array}$ & $\begin{array}{l}89.4 \\
10.6\end{array}$ & $\begin{array}{c}218 \\
30\end{array}$ & $\begin{array}{l}87.9 \\
12.1\end{array}$ & $6.73 \pm 1.07$ \\
\hline $\begin{array}{l}\text { Plain water consumption (ml/day) } \\
\text { Inadequate } \\
\text { Adequate } \\
\end{array}$ & $\begin{array}{c}171 \\
11 \\
\end{array}$ & $\begin{array}{c}93.9 \\
6.1 \\
\end{array}$ & $\begin{array}{c}64 \\
2 \\
\end{array}$ & $\begin{array}{c}96.9 \\
3.1 \\
\end{array}$ & $\begin{array}{c}235 \\
13 \\
\end{array}$ & $\begin{array}{c}94.8 \\
5.2 \\
\end{array}$ & $984.87 \pm 502.82$ \\
\hline $\begin{array}{l}\text { Sweet beverage consumption (ml/day) } \\
\text { Low } \\
\text { High }\end{array}$ & $\begin{array}{l}98 \\
84\end{array}$ & $\begin{array}{l}53.8 \\
46.2\end{array}$ & $\begin{array}{l}25 \\
41\end{array}$ & $\begin{array}{l}37.9 \\
62.1\end{array}$ & $\begin{array}{l}123 \\
125\end{array}$ & $\begin{array}{l}49.6 \\
50.4\end{array}$ & $430.67 \pm 284.83$ \\
\hline
\end{tabular}

Ovb adolescents had higher consumption of sweet beverages $(59.7 \%)$ than normal adolescents $(47.3 \%)$. Higher consumption of sweet beverages increased 1.65 times risk of obesity in adolescents (95\% CI=0.92-2.95), compared with lower consumption of sweet beverages but it was not statistically significance $(\mathrm{p}=0.092)$.

\section{TABLE II}

ASSOCIATION BETWEEN SEX, FAMILY HISTORY OF OBESITY, SLEEP DURATION AND CONSUMPTION OF PLAIN WATER AND SWEET BEVERAGES AND THE OBESITY RISK

\begin{tabular}{|c|c|c|c|c|c|c|}
\hline & \multicolumn{4}{|c|}{ Obesity risk $^{\mathrm{a}}$} & \multirow{3}{*}{$\begin{array}{c}\text { OR } \\
(95 \% \mathrm{CI})\end{array}$} & \multirow{3}{*}{$\mathbf{p}$} \\
\hline & \multicolumn{2}{|c|}{$\begin{array}{l}\text { Normal } \\
(\mathrm{n}=186)\end{array}$} & \multicolumn{2}{|c|}{$\begin{array}{c}\text { Ovb }^{b} \\
(n=62)\end{array}$} & & \\
\hline & $\mathrm{n}$ & $\%$ & $\mathrm{n}$ & $\%$ & & \\
\hline $\begin{array}{l}\text { Sex } \\
\quad \text { Female } \\
\text { Male }\end{array}$ & $\begin{array}{c}142 \\
44\end{array}$ & $\begin{array}{l}76.3 \\
23.7\end{array}$ & $\begin{array}{l}40 \\
22\end{array}$ & $\begin{array}{l}64.5 \\
35.5\end{array}$ & $\begin{array}{c}1.77 \\
(0.95-3.30)\end{array}$ & $0.068^{\mathrm{c}}$ \\
\hline $\begin{array}{l}\text { Family } \\
\text { History of } \\
\text { Obesity } \\
\quad \text { No } \\
\text { Yes }\end{array}$ & $\begin{array}{c}168 \\
18\end{array}$ & $\begin{array}{c}90.3 \\
9.7\end{array}$ & $\begin{array}{l}51 \\
11\end{array}$ & $\begin{array}{l}82.3 \\
17.7\end{array}$ & $\begin{array}{c}2.01 \\
(0.89-4.54)\end{array}$ & $0.087^{\mathrm{c}}$ \\
\hline $\begin{array}{l}\text { Sleep duration } \\
\text { Long } \\
\text { Short }\end{array}$ & $\begin{array}{c}19 \\
167\end{array}$ & $\begin{array}{l}10.2 \\
89.8\end{array}$ & $\begin{array}{l}11 \\
51\end{array}$ & $\begin{array}{l}17.7 \\
82.3\end{array}$ & $\begin{array}{c}0.53 \\
(0.24-1.18)\end{array}$ & $0.115^{\mathrm{c}}$ \\
\hline $\begin{array}{l}\text { Plain water } \\
\text { consumption } \\
\text { Adequate } \\
\text { Inadequate }\end{array}$ & $\begin{array}{c}9 \\
177 \\
\end{array}$ & $\begin{array}{c}4.8 \\
95.2 \\
\end{array}$ & $\begin{array}{c}4 \\
58 \\
\end{array}$ & $\begin{array}{c}6.4 \\
93.6 \\
\end{array}$ & $\begin{array}{c}0.74 \\
(0.22-2.48)\end{array}$ & $0.742^{d}$ \\
\hline $\begin{array}{l}\text { Sweet } \\
\text { beverage } \\
\text { consumption } \\
\text { Low } \\
\text { High }\end{array}$ & $\begin{array}{l}98 \\
88\end{array}$ & $\begin{array}{l}52.7 \\
47.3\end{array}$ & $\begin{array}{l}25 \\
37\end{array}$ & $\begin{array}{l}40.3 \\
59.7\end{array}$ & $\begin{array}{c}1.65 \\
(0.92-2.95)\end{array}$ & $0.092^{\mathrm{c}}$ \\
\hline
\end{tabular}

a. Data was categorized into 2: normal (5-85th percentile) and ovb ( 285 th percentile); b. Ovb: Overweight and obese c. Chi-square test; d. Fisher's exact test

After adjustment with sex and family history of obesity, there was no different risk of obesity in terms of short sleep duration and high consumption of sweet beverages (Table III). High consumption of sweet beverages had 1.62 times greater risk of obesity compared with low consumption of sweet beverages although it was no statistically significance. While short sleep duration decreased risk of obesity $(\mathrm{OR}=0.52$, 95\% $\mathrm{CI}=0.23-1.19 ; \mathrm{p}=0.121)$. Taken together, these four variables contributed only $6.7 \%$ of obesity risk in adolescents.

TABLE III

LOGISTIC REGRESSION ANALYSIS: WITH ODDS RATIO ACCORDING TO THE OBESITY RISK (NORMAL VS. OVB)

\begin{tabular}{|l|c|c|c|}
\hline & OR $(\mathbf{9 5 \%} \mathbf{C I})$ & $\mathbf{p}$ & $\begin{array}{c}\text { Nagelkerke } \\
\text { R square } \\
\mathbf{( \% )}\end{array}$ \\
\hline Sex (male) & $1.79(0.94-3.40)$ & 0.077 & 6.7 \\
\hline $\begin{array}{l}\text { Family history of } \\
\text { obesity (yes) }\end{array}$ & $2.33(1.00-5.42)$ & 0.050 & \\
\hline Sleep duration (short) & $0.52(0.23-1.19)$ & 0.121 & \\
\hline $\begin{array}{l}\text { Sweet beverage } \\
\text { consumption (high) }\end{array}$ & $1.62(0.88-2.96)$ & 0.118 & \\
\hline
\end{tabular}

\section{DISCUSSIONS}

In this present study, we reported that the highest number of adolescents in some senior high schools in Surakarta city was female. Obesity was found in one fourth among them, 
which $11.7 \%$ had family history of obesity. Obesity ratio in female and male adolescents was two third. The majority adolescents consumed less plain water and slept less than 8 hours. Ovb adolescents consumed more sweet beverages than normal adolescents. Therefore, it suggests that adolescents with high consumption of sweet beverages had greater risk of obesity than adolescents with low consumption of sweet beverages.

It is not surprising that obesity is more prominent in male than female adolescents. Our findings exhibited that male adolescents had shorter sleep duration, inadequate plain water consumption and higher consumption of sweet beverages than female adolescents (Table I). Our results are in agreement with Musaiger's study that the prevalence of obesity in male Kuwaiti adolescents are higher than female Kuwaiti adolescents (34.8\% vs. 20.6\%) [29]. Changing life style especially water consumption and sleep duration is a global problem in adolescent life. Bibiloni's study reported that male Spanish adolescents tent to consume lower plain water and higher sweet beverages than female Spanish adolescents [30]. According to Majeno's study which conducted in America, short sleep duration is commonly found in male adolescents as female adolescents [31].

Based on our data, the prevalence of obesity in adolescents is higher than the global and national prevalence of obesity [1], [2]. The discrepancy of these results may be caused by population and ethnic groups. Our study only used small population and the same ethnics group whilst global and national studies used a large number of population where came from different continents, countries and islands and recruited many ethnic groups who had different life style including water consumption and sleep duration [32].

Although sex and family history of obesity are not the main variables in our study, these variables increased 1.79 and 2.33 times risk of obesity in adolescents respectively. Our findings are as same result as Wang's study that male adolescents had 1.79 times risk of obesity [33]. Our study is also in accordance with Kumar's study in relation to family history of obesity. Family history has 25.2 times greater risk of obesity although this study was conducted in children who age 10-12 years old [34]. Overall, it indicates that sex, genetic factor and life style play an important role in adolescent obesity.

Short sleep duration is common condition in global adolescent life including adolescents in this study but our finding showed that sleep duration decreased obesity risk. Our data indicated that more than $80 \%$ normal and ovb adolescents had short sleep duration (Table II). Another reason is probably caused by different cut off point of sleep duration. In this present study, we used $<8$ hours for short sleep duration whilst another study used $<8.5$ hours for the cut off point of sleep duration [19]. According to Lee and Park (2014), 60.3\% Korean adolescents also had short sleep duration [20]. This is different from another study conducted in Austria. Children who aged 10-14 years old with short sleep duration had 2 times greater risk of obesity than their counterparts with long sleep duration [19]. Theoretically, short sleep duration can modulate neuroendocrine hormones like leptin and ghrelin which result in decrease of satiety and increase of hunger. These hormonal changes lead to increase energy intake and decrease energy expenditure which elevate the risk of obesity [35].

Most adolescents in this study consumed inadequate plain water which resulted in decrease obesity risk and no association between plain water consumption and obesity risk. Our finding is in agreement with another study that $54 \%$ American adolescents consumed less plain water $(<3$ times/day) [16]. In the other hand, the result of our study is different from Lakoro's study that low plain water consumption increased significantly 2.1 times risk of obesity [11]. The different result is probably caused by different the research method. We used the cross-sectional design and the other study used case-control design. Therefore, further study is required to determine properly the cut off point of plain water consumption in Indonesian adolescents.

From the data of our study, more than half of ovb adolescents consumed highly sweet beverages but it was not statistically significance due to small number of adolescents who participated in this study. One study performed in the UK documented that high consumption of sweet beverages had 2.53 times greater risk of obesity compared with low consumption of sweet beverages [17]. This study is suported by Qi's study that sugar-sweetened carbonated beverages had a significant association with obesity $(\mathrm{OR}=3.69)$ [36]. A study conducted in Mexico also reported that children who consumed less plain water would consume more sweet beverages, leading to increase by $20.7 \%$ energy intake [37]. Based on a survey in American adults, every $1 \%$ increased plain water consumption per day could decrease total energy and energy intake from sweet beverages [38]. So adequate consumption of plain water will stimulate the sympathetic nerves which increase thermogenesis and energy expenditure in brown adipose tissues and decrease energy intake [38], [39].

\section{CONCLUSIONS}

The prevalence of obesity in adolescents is high but we only analyzed restricted number of adolescents in six senior high schools in Surakarta city. Male adolescents have greater risk of obesity than female adolescents which high consumption of sweet beverages is the important risk factor of obesity. Adolescents should consider drinking more plain water to maintain their energy intake and energy expenditure.

\section{ACKNOWLEDGMENT}

We would like to thank Prof. Bhisma Murti, MD., MPH., M.SC., $\mathrm{PhD}$ for his assistance of statistical analysis, the headmaster of six senior high schools in Surakarta city for the opportunity to do this research study, and enumerators for their help in this research study.

\section{REFERENCES}

[1] World Health Organization (WHO). (2017) Obesity and overweight. [Online]. Available:http://www.who.int/mediacentre/factsheets/fs311 len/. 
[2] Health Research and Development Bureau, Basic Health Research in 2013. Jakarta, Indonesia: Indonesian Ministry of Health, Dec. 2013.

[3] Provincial Health of Central Java, Health Profile of Central Java Province in 2015. Semarang, Indonesia: Provincial Health of Central Java, May 2015.

[4] A. Abbasi, D. Juszczyk, C. H. M. van Jaarsveld, and M. C. Gulliford, "Body Mass Index and Incident Type 1 and Type 2 Diabetes in Children and Young Adults: A Retrospective Cohort Study," J. Endocr. Soc., vol. 1, no. 5, pp. 524-537, May 2017

[5] F. Chen, Y. Wang, X. Shan, D. Hou, X. Zhao, T. Wag, D. Zhao, and J. Mi, "Association between Childhood Obesity and Metabolic Syndrome: Evidence from a Large Sample of Chinese Children and Adolescents," PLOS ONE, vol. 7, no. 10, p. e47380, Oct. 2012.

[6] J. Rankin, L. Matthews, S. Cobley, A. Han, R. Sanders, H. D Wiltshire, and J. S. Baker, "Psychological consequences of childhood obesity: psychiatric comorbidity and prevention," Adolesc. Health Med. Ther., vol. Volume 7, pp. 125-146, Nov. 2016.

[7] K. Sahoo, B. Sahoo, A. Choudhury, N. Sofi, R. Kumar, and A Bhadoria, "Childhood obesity: Causes and consequences," J. Fam. Med. Prim. Care, vol. 4, no. 2, p. 187, 2015.

[8] A. D. Utami, "Pengaruh Perilaku Jajan, Aktivitas Fisik, Lingkungan Makanan Sekolah dan Faktor Sosial Ekonomi terhadap Indeks Massa Tubuh dan Stunting Anak Sekolah Dasar," M. Public Health, Thesis, Universitas Sebelas Maret, Surakarta, Indonesia, Jun. 2017

[9] M. Akiyama, Y. Okada, M. Kanai, A. Takahashi, Y. Momozaawa, M Ikeda, N. Iwata, S. Ikegawa, M. Hirata, K. Matsuda, M. Iwasaki, T. Yamaji, N. Sawada, T. Hachiya, K. Tanno, A. Shimizu, A. Hozawa, N. Minegishi, S. Tsugane, M. Yamamoto, M. Kubo, and Y. Kamatani, "Genome-wide association study identifies 112 new loci for body mass index in the Japanese population," Nat. Genet., vol. 49, no. 10 pp. 1458-1467, Sep. 2017.

[10] M. W. Schwartz, R. J. Seeley, L. M. Zeltser, A. Drewnowski, E. Ravussin, L. M. Redman, and R. L. Leibel, "Obesity Pathogenesis: An Endocrine Society Scientific Statement," Endocr. Rev., vol. 38, no. 4, pp. 267-296, Aug. 2017.

[11] Y. Lakoro, H. Hadi, and M. Julia, "Pola konsumsi air, susu dan produk susu, serta minuman manis sebagai faktor risiko obesitas pada anak sekolah dasar di Kota Yogyakarta dan Kabupaten Bantul," J. Gizi Dan Diet. Indones., vol. 1, no. 2, p. 102, Mar. 2016.

[12] J. Vilchis-Gil, M. Galván-Portillo, M. Klünder-Klünder, M. Cruz, and S. Flores-Huerta, "Food habits, physical activities and sedentary lifestyles of eutrophic and obese school children: a case-control study," BMC Public Health, vol. 15, no. 1, Dec. 2015

[13] J.-P. Chaput and C. Dutil, "Lack of sleep as a contributor to obesity in adolescents: impacts on eating and activity behaviors," Int. J. Behav. Nutr. Phys. Act., vol. 13, no. 1, Dec. 2016.

[14] G. Dubnov-Raz, N. W. Constantini, H. Yariv, S. Nice, and N. Shapira, "Influence of water drinking on resting energy expenditure in overweight children," Int. J. Obes., vol. 35, no. 10, pp. 1295-1300, Oct. 2011.

[15] V. A. Vij and A. Joshi, "Effect of excessive water intake on body weight, body mass index, body fat, and appetite of overweight female participants," J. Nat. Sci. Biol. Med., vol. 5, no. 2, p. 340, 2014

[16] S. Park, H. M. Blanck, B. Sherry, N. Brener, and T. O'Toole, "Factors Associated with Low Water Intake among US High School Students-National Youth Physical Activity and Nutrition Study, 2010," J. Acad. Nutr. Diet., vol. 112, no. 9, pp. 1421-1427, Sep. 2012

[17] N. Martin-Calvo, M. Martinez-Gonzalez, M. Bes-Rastrollo, A. Gea M. C. Ochoa, A. Marti, and GENOI Members, "Sugar-sweetened carbonated beverage consumption and childhood/adolescent obesity: a case-control study," Public Health Nutr., vol. 17, no. 10, pp. 2185 2193, Oct. 2014

[18] A. Weiss, F. Xu, A. Storfer-Isser, A. Thomas, C. E. Ievers-Landis, and S. Redline, "The Association of Sleep Duration with Adolescents' Fat and Carbohydrate Consumption," Sleep, vol. 33, no. 9, pp. 12011209, Sep. 2010

[19] E.-M. Wendt, E. Pernerstorfer, J. Möseneder, G. Karner, and St. Pölten/Austria, "Association between sleep duration and body-massindex in 10- to 14-yearold Austrians," Ernahrungs Umsch., pp. 124 131, Aug. 2013.
[20] J. A. Lee and H. S. Park, "Relation between sleep duration, overweight, and metabolic syndrome in Korean adolescents," Nutr. Metab. Cardiovasc. Dis., vol. 24, no. 1, pp. 65-71, Jan. 2014

[21] B. Morrissey, M. Malakellis, J. Whelan, L. Millar, B. Swinburn, S Allender, and C. Strugnell, "Sleep duration and risk of obesity among a sample of Victorian school children," BMC Public Health, vol. 16, no. 1 , Dec. 2016

[22] S. Sastroasmoro and S. Ismael, Dasar-Dasar Metodologi Penelitian Klinis, Edisi Ke-4. Jakarta, Indonesia: Sagung Seto, 2011.

[23] M. Hirshkowitz, K. Whiton, S. M. Albert, C. Alessi, O. Bruni, L. Don Carlos, N. Hazen, J. Herman, E. S. Katz, L. Kheirandish-Gozal, D. N. Neubauer, A. E. O'Donnel, M. Ohayon, J. Peever. R. Rawdong, R. c. Sachdeva, B. Setters, M. V. Vitiello, J. C. Ware, and P. J. Adams Hillard, "National Sleep Foundation's sleep time duration recommendations: methodology and results summary," Sleep Health, vol. 1 , no. 1 , pp. 40-43, Mar. 2015.

[24] Indonesian Minister of Health, Balanced Nutrition Guidelines. Jakarta Indonesia: Indonesian Ministry of Health, 2014

[25] Y. Kawaguchi et al., "Mushroom Intake and Advanced Glycation End Products in the Skin among Community-Dwelling Elderly Subjects: Preliminary Data," J. Biomed., vol. 2, pp. 8-11, 2017.

[26] Centers for Disease Control and Prevention (CDC). (2015) About Child \& Teen BMI. [Online]. Available: https://www.cdc.gov/ healthyweight/assessing/bmi/childrens_bmi/about_childres_bmi.html.

[27] M. S. Dahlan, Statistik untuk Kedokteran dan Kesehatan Edisi Ke-5. Jakarta, Indonesia: Salemba Medika, 2011.

[28] M. Szumilas, "Explaining odds ratios," J. Can. Acad. Child Adolesc. Psychiatry, vol. 19, no. 3, p. 227, 2010.

[29] A. O. Musaiger, M. Al-Mannai, R. Tayyem, O. Al-Lalla, E. Y. H. Ali, F. Kalam, M. M. Benhamed, S. Saghir, I. Halahleh, Z. Djoudi, and M. Chirane, "Prevalence of Overweight and Obesity among Adolescents in Seven Arab Countries: A Cross-Cultural Study," J. Obes., vol. 2012, pp. 1-5, 2012

[30] M. Bibiloni, A. Özen, A. Pons, M. González-Gross, and J. Tur, "Physical Activity and Beverage Consumption among Adolescents," Nutrients, vol. 8, no. 12, p. 389, Jun. 2016.

[31] A. Majeno, K. M. Tsai, V. W. Huynh, H. McCreath, and A. J. Fuligni, "Discrimination and Sleep Difficulties during Adolescence: The Mediating Roles of Loneliness and Perceived Stress," J. Youth Adolesc., vol. 47, no. 1, pp. 135-147, Jan. 2018.

[32] M. C. Ford, N. P. Gordon, A. Howell, C. E. Green, L. C.. Greenspan, M. Chandra, R. G. Mellor, and J. C. Lo, "Obesity Severity, Dietary Behaviors, and Lifestyle Risks Vary by Race/Ethnicity and Age in a Northern California Cohort of Children with Obesity," J. Obes., vol. 2016, pp. 1-10, 2016.

[33] L. Wang, D. L. Slawson, G. Relyea, J. L. Southerland, and Y. Wang, "Prevalence of and Risk Factors for Adolescent Obesity in Southern Appalachia, 2012," Prev. Chronic. Dis., vol. 11, Dec. 2014.

[34] S. Kumar, M. Raju, and N. Gowda, "Influence of parental obesity on school children," Indian J. Pediatr., vol. 77, no. 3, pp. 255-258, Mar. 2010.

[35] K. L. Knutson, K. Spiegel, P. Penev, and E. Van Cauter, "The metabolic consequences of sleep deprivation," Sleep Med. Rev., vol. 11, no. 3, pp. 163-178, 2007

[36] Q. Qi, A. Y. Chu, J.H. Kang, M. K. Jensen, G. C. Curhan, L. R. Pasquale, P. M. Ridker, D. J. Hunter, W. C. Willett, E. B. Rimm, D. I. Chasman, F. B. Hu, and L. Qi, "Sugar-Sweetened Beverages and Genetic Risk of Obesity," N. Engl. J. Med., vol. 367, no. 15, pp. 1387-1396, Oct. 2012

[37] T. Shamah-Levy, C. García-Chávez, and S. Rodríguez-Ramírez, "Association between Plain Water and Sugar-Sweetened Beverages and Total Energy Intake among Mexican School-Age Children," Nutrients, vol. 8, no. 12, p. 710, Dec. 2016

[38] R. An and J. McCaffrey, "Plain water consumption in relation to energy intake and diet quality among US adults, 2005-2012," J. Hum. Nutr. Diet., vol. 29, no. 5, pp. 624-632, Oct. 2016.

[39] M. Boschmann, J. Steiniger, G. Franke, A. L. Birkenfeld, F. C. Luft and J. Jordan, "Water Drinking Induces Thermogenesis through Osmosensitive Mechanisms," J. Clin. Endocrinol. Metab., vol. 92, no. 8, pp. 3334-3337, Aug. 2007. 